\title{
FLYPAPER EFFECT PADA PENDAPATAN ASLI DAERAH(PAD), DANA BELANJA DAERAH PADA PEMERINTAHAN KABUPATEN/KOTA DI JAWA TENGAH TAHUN 2015-2016
}

\author{
Sri Handayani \\ Saifudin \\ Fakultas Ekonomi Universita Semarang (USM) \\ Diterima: April 2018. Disetujui: Juli 2018. Dipublikasikan: Oktober 2018
}

\begin{abstract}
This study aims to find out the flypaper effect on Regional Original Revenue (PAD), General Allocation Funds (DAU), and Special Allocation Funds (DAK) for Regional Expenditures in district / city governments in Central Java over the period 2015 to 2016.

The data used are secondary data using the 2015-2016 period in the regencies / cities in Central Java. Where there are 29 districts / cities observed. Observations of 68 observations from 35 districts / cities were observed for 2 periods. The data analysis method used in this study was descriptive statistical analysis and linear regression analysis using SPSS (Statistical Products and Service Solutions) version 20.

The results showed that: (1) PAD had an effect on regional expenditure, (2) DAU had an effect on regional expenditure, (3) DAK had no effect on regional expenditure, and (4) Based on the results of multiple regression, it was known that the DAU variable in each each regional condition has a stronger influence on Regional Expenditures than the influence of PAD on Regional Expenditures. This indicates that the flypaper effect does not only occur in regions with low PAD but also in regions with high $P A D$.
\end{abstract}

Keywords: Regional Original Income (PAD), General Allocation Fund (DAU), Special Allocation Fund (DAK), Flypaper Effect

\begin{abstract}
ABSTRAK
Penelitian ini bertujuan untuk mengetahui flypaper effect pada Pendapatan Asli Daerah (PAD), Dana Alokasi Umum (DAU), dan Dana Alokasi Khusus (DAK) terhadap Belanja Daerah pada pemerintahan kabupaten/kota di Jawa Tengah selama periode tahun 2015 sampai 2016.

Data yang digunakan adalah data sekunder dengan menggunakan periode 2015-2016 pada Kabupaten/Kota di Jawa Tengah. Dimana terdapat 29 Kabupaten/Kota yang diamati. Pengamatan sebanyak 68 pengamatan dari 35 Kabupaten/kota yang diamati selama 2 periode. Metode analisis data yang digunakan dalam penelitian ini adalah analisis statistik deskriptif dan analisis regresi linear menggunakan SPSS (Statistik Produk dan Layanan Solusi) versi 20.

Hasil penelitian menunjukkan bahwa: (1) PAD berpengaruh terhadap belanja daerah, (2) DAU berpengaruh terhadap belanja daerah, (3) DAK tidak berpengaruh terhadap belanja daerah, dan (4) Berdasarkan hasil regresi berganda tersebut, diketahui bahwa variabel DAU pada masing-masing kondisi daerah memiliki pengaruh lebih kuat terhadap Belanja Daerah daripada pengaruh PAD terhadap Belanja Daerah. Ini mengindikasikan bahwa flypaper effect tidak hanya terjadi pada daerah dengan $\mathrm{PAD}$ rendah namun juga pada daerah dengan PAD tinggi.

Kata kunci : Pendapatan Asli Daerah(PAD), Dana Alokasi Umum(DAU), Dana Alokasi Khusus(DAK), Flypaper Effect
\end{abstract}




\section{PENDAHULUAN}

Menurut Undang-Undang Nomor 32 Tahun 2004 tentang Pemerintah Daerah menjelaskan bahwa desentralisasi merupakan penyerahan wewenang pemerintahan oleh Pemerintah Pusat kepada Pemerintah Daerah (PEMDA) untuk mengatur dan mengurus urusan pemerintahan. Desentralisasi mempunyai tujuan untuk lebih meningkatkan kesejahteraan dan pelayanan kepada masyarakat, pengembangan kehidupan berdemokrasi, keadilan, pemerataan, dan pemeliharaan hubungan yang serasi antara pusat dan daerah dan antar daerah (Sidik, 2002 dalam Marissa Ayu Saputri, 2014).

Fenomena flypaper effect merupakan suatu kondisi yang terjadi saat pemerintah daerah mengeluarkan belanja lebih banyak dengan menggunakan dana transfer daripada menggunakan kemampuan sendiri yang diproksikan dengan PAD. Apabila ketergantungan pemerintah daerah terhadap dana transfer lebih besar daripada ketergantungan terhadap pendapatan asli daerah, maka hal tersebut diindikasi telah terjadi flypaper effect.

Beberapa peneliti sebelumnya telah meneliti pengaruh DAU, DAK, PAD terhadap Belanja Daerah. Beberapa penelitian di Indonesia menyimpulkan telah terjadi fenomena flypaper effect, para peneliti membandingkan pengaruh dana transfer dengan PAD maupun variabel pendapatan lainnya terhadap belanja daerah dalam penelitian flypaper effect.

\section{TELAAH PUSTAKA}

\section{Flypaper effect}

Flypaper effect merupakan suatu kondisi stimulus terhadap pengeluaran daerah yang disebabkan oleh adanya perubahan dalam jumlah transfer (unconditional grants) dari pemerintah pusat lebih besar dari yang disebabkan oleh perubahan dalam pendapatan daerah (Iskandar, 2012 dalam Solikin, 2016). Menurut Nahlia (2014) dalam Wia Rizqi Amalia (2015), menganggap sebagai suatu anomali dalam perilaku rasional jika transfer harus dianggap sebagai tambahan pendapatan masyarakat (seperti halnya pajak daerah), sehingga harus 
dibelanjakan dengan cara yang sama pula dengan PAD. Fenomena tersebut membawa implikasi lebih luas bahwa transfer akan meningkatkan belanja pemerintah daerah lebih besar daripada penerimaan transfer itu sendiri.

\section{Pendapatan Asli Daerah (PAD)}

Menurut Undang-Undang Nomor 33 Tahun 2004 yang dimaksud dengan PAD adalah pendapatan daerah yang bersumber dari hasil pajak daerah, hasil retribusi daerah, hasil pengelolaan kekayaan daerah yang dipisahkan, dan lain-lain PAD yang sah. PAD bertujuan untuk memberikan keleluasaan kepada daerah dalam menggali pendanaan dalam pelaksanaan otonomi daerah sebagai perwujudan asas desentralisasi. PAD sebagai salah satu komponen pendapatan memiliki peran penting dalam pengeluaran belanja pemerintah daerah karena untuk mendanai kebutuhan belanja yang tinggi memerlukan sumber pendanaan yang mencukupi.

\section{Dana Alokasi Umum (DAU)}

Menurut Undang-Undang No 33 Tahun 2004, Dana alokasi umum adalah dana yang bersumber dari pendapatan APBN yang dialokasikan dengan tujuan pemerataan kemampuan keuangan antar daerah untuk mendanai kebutuhan daerah dalam pelaksanaan desentralisasi. Pembagian dana untuk daerah melalui bagi hasil berdasarkan daerah penghasil cenderung menimbulkan ketimpangan antar daerah dengan mempertimbangkan kebutuhan dan potensi daerah. Alokasi dana umum bagi daerah yang potensi fiskalnya besar namun kebutuhan fiskalnya kecil akan memperoleh alokasi dana umum yang relatif kecil. Sebaliknya daerah yang memiliki potensi fiskalnya kecil namun kebutuhan fiskalnya besar akan memperoleh alokasi dana umum relatif besar.

\section{Dana Alokasi Khusus (DAK)}

DAK merupakan salah satu jenis transfer danaperimbangan yang dialokasikan kepada pemerintah daerah tertentu untuk mendanai kegiatan khusus yang merupakan bagian dari program yang menjadi prioritas nasional dan menjadi urusan daerah. Program yang menjadi prioritas nasional harus dimuat dalam rencana kerja pemerintah (RKP) tahun anggaran bersangkutan. 
Menurut Nordiawan, 2012 dalam Amalia, 2015 penggunaan alokasi DAK perdaerah yang ditetapkan dalam Peraturan Menteri Keuangan harus dilakukan sesuai Petunjuk Teknis Penggunaan DAK dan tidak digunakan untuk mendanai administrasi kegiatan, penyiapan kegiatan fisik, penelitian, pelatihan, dan perjalanan dinas.

\section{Belanja Daerah}

Belanja Daerah adalah semua kewajiban Daerah yang diakui sebagai pengurang nilai kekayaan bersih dalam periode tahun anggaran yang bersangkutan. Belanja Daerah terdiri dari Belanja Tak Langsung dan Belanja Langsung.

\section{Hubungan Logis Antar Variabel dan Perumusan Hipotesis \\ Hubungan Pendapatan Asli Daerah (PAD) Terhadap Belanja Daerah}

Pendapatan Asli Daerah (PAD) merupakan salah satu sumber pendapatan daerah yang terdiri dari hasil pajak daerah, hasil retribusi daerah, hasil pengelolaan kekayaan daerah yang dipisahkan dan lain-lain Pendapatan Asli Daerah (PAD) yang sah. Peningkatan Pendapatan Asli Daerah (PAD) diharapkan dapat meningkatkan belanja pemerintah daerah sehingga dapat mendukung program dan kegiatan pemerintah.

Hasil Penelitian Maimunah (2006) dalam Wia Rizqi Amalia (2015), Utama (2011) dalam Solikin (2016), Iskandar (2012) dalam Solikin (2016), Kang (2012) dalam Solikin (2016), Darmayasa (2012) dalam Wia Rizqi Amalia (2015), Nahlia (2014) dalam Wia Rizqi Amalia (2015) menunjukan bahwa Pendapatan Asli Daerah (PAD) berpengaruh terhadap belanja daerah.

\section{H1 : Diduga Pendapatan Asli Daerah (PAD) berpengaruh terhadap Belanja} Daerah.

\section{Hubungan Dana Alokasi Umum (DAU) Terhadap Belanja Daerah}

Dana Alokasi Umum (DAU) termasuk dana transfer dari pemerintah pusat yang bersifat unconditional grant (transfer tidak bersyarat). Pemerintah pusat memberikan keleluasaan kepada pemerintah daerah dalam pemanfaatan Dana 
Alokasi Umum (DAU) untuk mengalokasikannya sesuai dengan prioritas daerah. Tujuan pemberian grant ini adalah untuk mendukung ketersediaan dana dalam memenuhi kebutuhan belanja daerah dalam menjalankan fungsi yang telah didesentralisasikan.

Hasil penelitian Maimunah (2006) dalam Wia Rizqi Amalia (2015), Utama (2011) dalam Solikin (2016), Listiorini (2012) dalam Luluk Atika Rahmawati (2015) serta Iskandar (2012) dalam Solikin (2016) menunjukkan bahwa Dana Alokasi Umum (DAU) berpengaruh terhadap belanja daerah.

H2 : Diduga Dana Alokasi Umum (DAU) berpengaruh terhadap Belanja Daerah.

\section{Hubungan Dana Alokasi Khusus (DAK) Terhadap Belanja Daerah}

Menurut Kuncoro (2011) dalam Wia Rizqi Amalia (2015) salah satu persyaratan untuk menerima Dana Alokasi Khusus (DAK) adalah daerah perlu membuktikan bahwa daerah kurang mampu membiayai seluruh pengeluaran usulan kebutuhan tersebut dari Pendapatan Asli Daerah, Bagi Hasil Pajak dan Sumber Daya Alam, Dana Alokasi Umum, Pinjaman Daerah, dan lain-lain penerimaan yang sah. Artinya, Dana Alokasi Khusus sebagai salah satu komponen pendapatan daerah juga diperlukan daerah untuk mencukupi kebutuhan pengeluaran belanja, namun untuk kebutuhan yang bersifat lebih spesifik.

Penelitian sebelumnya yang dilakukan oleh Nahlia (2014) dalam Wia Rizqi Amalia (2015) menyimpulkan Dana Alokasi Khusus (DAK) berpengaruh terhadap belanja daerah, namun tidak signifikan. Ketika terjadi peningkatan Dana Alokasi Khusus (DAK), maka belanja daerah juga meningkat namun tidak signifikan. Sebaliknya, penelitian yang dilakukan Listiorini (2012) dalam Wia Rizqi Amalia (2015) menyimpulkan Dana Alokasi Khusus (DAK) tidak berpengaruh dan tidak signifikan terhadap belanja daerah.

H3 : Diduga Dana Alokasi Khusus (DAK) berpengaruh terhadap Belanja Daerah

Flypaper Effect pada Daerah Kaya dan Miskin 
Semakin tinggi Pendapatan Asli Daerah suatu daerah maka kemampuan untuk membiayai belanja daerah semakin besar dan rasio ketergantungan keuangan daerah semakin kecil dan flypaper effect juga menurun. Sebaliknya, semakin rendah Pendapatan Asli Daerah suatu daerah maka kemampuan untuk membiayai belanja daerah semakin kecil dan rasio ketergantungan keuangan daerah semakin besar dan flypaper effect juga meningkat.

Pada penelitian yang dilakukan Maimunah (2006) dalam Marissa Ayu Saputri (2014) diketahui bahwa tidak terdapat perbedaan terjadinya flypaper effect baik pada daerah yang Pendapatan Asli Daerahnya tinggi maupun pada daerah yang Pendapatan Asli Daerahnya rendah (yang diukur melalui rasio DOF masingmasing daerah ) di Kabupaten/Kota di Pulau Sumatera. Ini berarti flypaper effect yang terjadi pada daerah kaya Pendapatan Asli Daerah tidak berbeda dengan flypaper effect yang terjadi pada daerah miskin Pendapatan Asli Daerah. Dengan kata lain, flypaper effect tidak hanya terjadi pada daerah miskin Pendapatan Asli Daerah, namun juga daerah kaya Pendapatan Asli Daerah. Berdasarkan pada hal tersebut maka penulis menarik hipotesis sebagai berikut :

H4 : Diduga Daerah dengan Pendapatan Asli Daerah Rendah dan Pendapatan Asli Daerah Tinggi mengalami Flypaper Effect.

\section{Kerangka Pemikiran}

Kerangka pemikiran untuk pengembangan hipotesis pada penelitian dapat digambarkan sebagai berikut :

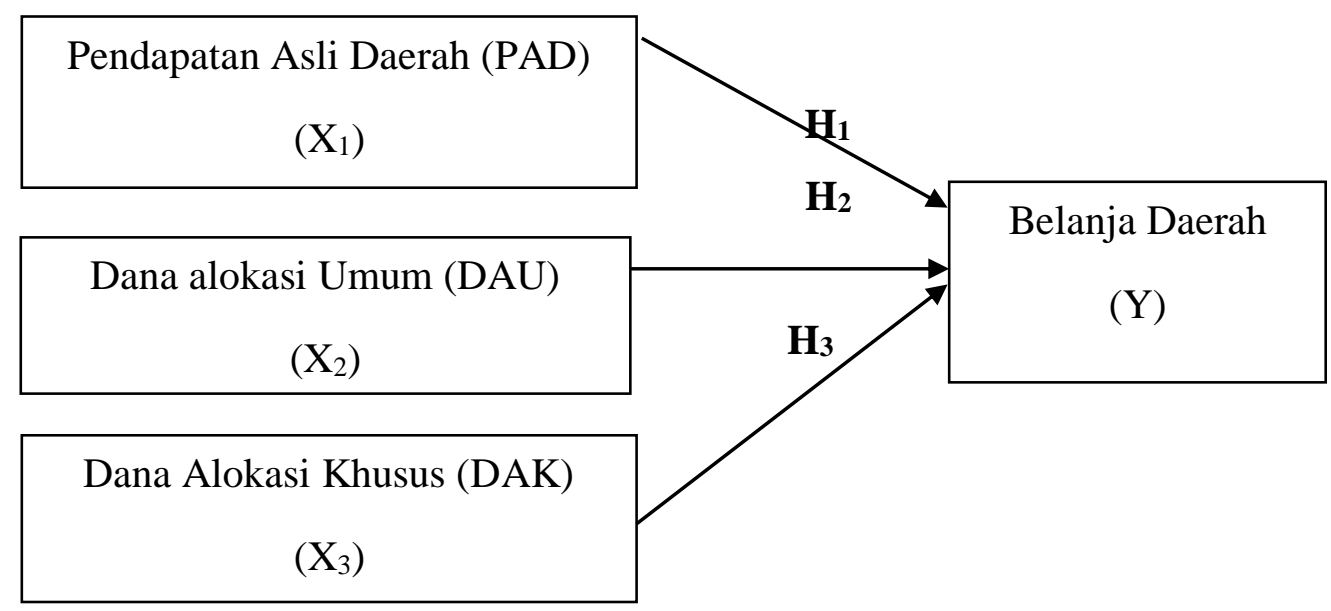




\section{METODE PENELITIAN}

\section{Variabel Penelitian dan Definisi Operasional}

Dalam penelitian ini terdapat satu variabel Dependen dan tiga variabel Independen, variabel tersebut antara lain : Variabel Dependen dalam penelitian ini adalah Belanja Daerah. Variabel Independen dalam penelitian ini adalah Pendapatan Asli Daerah (PAD), Dana Alokasi Umum (DAU), Dana Alokasi Khusus (DAK).

\section{Objek Penelitian, Unit Sampel, Populasi dan Teknik Pengambilan Sempel}

Objek penelitian ini adalah mengenai Pendapatan Asli Daerah (PAD), Dana Alokasi Umum (DAU), Dana Alokasi Khusus (DAK) dan Belanja Daerah. Unit Sampel yang digunakan dalam penelitian ini adalah Laporan Realisasi Anggaran dan Belanja Daerah Kabupaten/Kota di Provinsi Jawa Tengah tahun 2015-2016. Populasi dalam penelitian ini adalah Laporan Realisasi Anggaran Pendapatan dan Belanja Daerah Kota/kabupaten di Jawa Tengah tahun 2015-2016.

\section{Teknik Pengambilan Sampel}

Teknik penelitian ini menggunakan metode purposive sampling. Metode purposive sampling merupakan metode pengambilan sampel dengan memilih sampel berdasarkan kriteria yang sesuai dengan data yang dibutuhkan dalam penelitian.

\section{Jenis dan Sumber Data}

Jenis data yang digunakan dalam penelitian ini adalah data sekunder, yaitu berupa laporan realisasi APBD, realisasi PAD, DAU, DAK dan Belanja Daerah Kabupaten/Kota di Provinsi Jawa Tengah selama periode pengamatan yaitu tahun 2015-2016. Sumber data dalam penelitian ini diperoleh dari Badan Pusat Statistik (BPS) Jawa Tengah.

\section{Metode Pengumpulan Data}

Metode pengumpulan data dalam penelitian ini adalah metode dokumentasi. Metode dokumentasi adalah pengumpulan data melalui studi pustaka pada laporan historis yang telah disusun dalam arsip. 


\section{Metode Analisis Data}

\section{Analisis Statistik Deskriptif}

Menurut Ghozali (2013) analisis statistik deskriptif digunakan untuk memberikan gambaran atau deskripsi suatu data yang dilihat dari nilai rata-rata (mean), standar deviasi, maksimum, minimum, sum, range, kurtosis dan skewness (kemencengan distribusi).

\section{Pengujian Asumsi Klasik}

\section{Uji Normalitas}

Uji normalitas dilakukan untuk menguji apakah dalam model regresi, variabel pengganggu atau residual memiliki distribusi normal (Ghozali, 2013). Pengujian normalitas juga dapat dilakukan dengan uji statistik Kolmogorov-Smirnov (K-S) dengan melihat tingkat signifikansinya. Kriteria pengambilan keputusan: Kolmogrov-Smirnov menunjukkan nilai signifikan >0,05 maka data residual terdistribusi dengan normal sedangkan Jika hasil Kolmogrov-Smirnov menunjukkan nilai signfikan $<0,05$ maka data residual terdistribusikan tidak normal.

\section{Uji Multikolinearitas}

Uji multikolinearitas bertujuan untuk menguji apakah dalam suatu model regresi ditemukan adanya korelasi atau hubungan yang signifikan antar variabel bebas (Ghozali, 2013). Multikolinearitas dapat dilihat dari (1) nilai tolerance dan lawannya (2) Variance Inflation Factor (VIF). Kedua ukuran ini menunjukan setiap variabel bebas manakah yang dijelaskan oleh variabel bebas lainnya. Nilai cut off yang umum dipakai untuk menunjukan adanya multikolinearitas adalah nilai tolerance $<0,10$ atau sama dengan niali VIF $>10$.

\section{Uji Autokorelasi}

Uji autokorelasi bertujuan untuk menguji apakah dalam model regresi linear ada korelasi antara kesalahan penggangu pada periode $t$ dengan kesalahan penggangu pada periode t-1 (sebelumnya) Ghozali (2013). Salah satu cara yang 
dapat digunakan untuk mendeteksi ada atau tidaknya autokorelasi digunakan uji Durbin Watson $(D W)$, dimana dalam pengambilan keputusan dengan melihat berapa jumlah sampel yang diteliti yang kemudian dilihat angka ketentuannya pada tabel Durbin Watson.

\section{Uji Heteroskedastisitas}

Menurut Ghozali (2013) Uji heteroskedastisitas bertujuan untuk menguji apakah dalam suatu model regresi terjadi ketidaksamaan varians dari residual satu pengamatan ke pengamatan lain. Hal ini dapat dilihat dari probabilitas signifikansinya jika diatas tingkat kepercayaan 5\% atau diatas 0,05, maka dapat disimpulkan model regresi tidak mengandung adanya heteroskedastisitas.

\section{Analisis Regresi Linear Berganda}

Metode analisis yang digunakan dalam penelitian ini adalah analisis regresi linear berganda (Multiple Regression). Analisi regresi linear berganda adalah model linear regresi yang variabel dependennya merupakan fungsi linear dari beberapa variabel bebas. Analisis ini secara matematis ditulis dengan menggunakan persamaan regresi linear berganda sebagai berikut :

$$
Y=\alpha+\beta_{1} X_{1}+\beta_{2} X_{2}+\beta_{3} X_{3}+e
$$

Dimana :

$$
\begin{aligned}
& \mathrm{Y}=\text { Belanja Daerah } \\
& \alpha \quad=\text { Konstanta } \\
& \mathrm{X}_{1}=\text { Pendapatan Asli Daerah (PAD) } \\
& \mathrm{X}_{2}=\text { Dana Alokasi Umum (DAU) } \\
& \mathrm{X}_{3}=\text { Dana Alokasi Khusus (DAK) } \\
& \beta_{1} \beta_{2} \beta_{3}=\text { Koefisien regresi untuk masing-masing variabel } \mathrm{X} . \\
& \mathrm{e} \quad=\text { Error }
\end{aligned}
$$




\section{Pengujian Hipotesis}

\section{Koefisien Determinasi $\left(\mathbf{R}^{2}\right)$}

Koefisien determinasi $\left(\mathrm{R}^{2}\right)$ pada intinya mengukur seberapa jauh kemampuan model dalam menerangkan variabel dependen/ terikat. Nilai koefisien determinasi adalah antara nol dan satu. Secara matematis jika nilai $\mathrm{R}^{2}=1$, maka Adjust $\mathrm{R}^{2}=\mathrm{R}^{2}=1$ sedangkan jika nilai $\mathrm{R}^{2}=0$, maka adjusted $\mathrm{R}^{2}=(1-\mathrm{k}) /(\mathrm{n}-\mathrm{k})$. Jika $\mathrm{k}>1$, maka adjusted $\mathrm{R}^{2}$ akan bernilai negatif.

\section{Uji Simultan (Uji F)}

Uji statistik F pada dasarnya menunjukkan apakah semua variabel independen atau bebas yang dimasukkan dalalm model mempunyai pengaruh secara bersama-sama terhadap variabel terikat atau dependen (Ghozali, 2013). Untuk menguji hipotesis ini, digunakan statistik $\mathrm{F}$ dengan membandingkan $\mathrm{F}_{\text {hitung }}$ dengan $F_{\text {tabel }}$ dengan kriteria pengambilan keputusan sebagai berikut :

a. $\quad$ Bila $F_{\text {hitung }}>F_{\text {tabel }}$ atau probabilitas $<$ nilai signifikan $(\mathrm{Sig} \leq 0,05)$, maka hipotesis tidak dapat ditolak, ini berarti bahwa secara simultan variabel independen mempunyai pengaruh signifikan terhadap variabel dependen.

b. Bila $F_{\text {hitung }}<F_{\text {tabel }}$ atau probabilitas $>$ nilai signifikan (Sig $\left.\geq 0,05\right)$, maka hipotesis tidak dapat diterima, ini berarti bahwa secara simultan variabel independen tidak mempunyai pengaruh signifikan terhadap variabel dependen.

\section{Uji Parsial (Uji t)}

Uji statistik t pada dasarnya menunjukkan seberapa jauh pengaruh satu variabel independen secara individual dalam menerangkan variasi variabel dependen dan digunakan untuk mengetahui ada atau tidaknya pengaruh masing-masing variabel independen terhadap variabel dependen yang diuji pada tingkat signifikansi 0.05 (Ghozali, 2013). Cara pengujiannya adalah sebagai berikut 
a. Bila $t_{\text {hitung }}>$ dari $t_{\text {tabel }}$ atau probabilitas lebih kecil dari tingkat signifikansi ( $\mathrm{Sig}<0,05)$ maka $\mathrm{H}_{\mathrm{a}}$ diterima dan $\mathrm{H}_{\mathrm{o}}$ ditolak, variabel bebas berpengaruh terhadap variabel terikat.

b. Bila thitung $<$ dari tabel atau probabilitas lebih besar dari tingkat signifikansi $(\mathrm{Sig}>0,05)$ maka $\mathrm{H}_{\mathrm{a}}$ ditolak dan $\mathrm{H}_{\mathrm{o}}$ diterima, variabel bebas tidak berpengaruh terhadap variabel terikat.

\section{HASIL PENELITIAN DAN PEMBAHASAN}

\section{Deskripsi Obyek Penelitian}

Data sampel penelitian ini adalah data yang diambil dari pemerintah daerah kabupaten dan kota se-Jawa Tengah antara lain data Pendapatan Asli Daerah, Dana Alokasi Umum, Dana Alokasi Khusus, dan data Belanja daerah selama tahun 2015 sampai dengan 2016 yang diperoleh dari BPS Pusat dan BPS Jawa Tengah dan melalui situs internet dengan alamat http://www.bps.go.id/. Dari perhitungan berdasarkan kriteria diperoleh sampel yang digunakan dalam penelitian ini adalah:

Tabel 1 Penentuan Jumlah Sampel

\begin{tabular}{|l|c|}
\hline \multicolumn{1}{|c|}{ Kriteria } & Jumlah Sampel \\
\hline $\begin{array}{l}\text { Kabupaten/kota di Jawa Tengah yang mempublikasikan laporan } \\
\text { realisasi APBD tahunan di situs Badan Pusat Statistik (BPS) } \\
\text { (www.bps.go.id.) periode 2015 hingga 2016 }\end{array}$ & 35 \\
\hline $\begin{array}{l}\text { Kabupaten/kota di Jawa Tengah yang mempublikasikan laporan } \\
\text { realisasi PAD, DAU, DAK dan Belanja Daerah di situs Badan Pusat } \\
\text { Statistik (BPS) (www.bps.go.id.) periode 2015 hingga 2016 }\end{array}$ & 35 \\
\hline $\begin{array}{l}\text { Jumlah realisasi PAD, DAU, DAK dan Belanja Daerah di situs Badan } \\
\text { Pusat Statistik (BPS) (www.bps.go.id.) periode 2015 hingga 2016 yang } \\
\text { minus (negatif) dan 0 (nol). }\end{array}$ & $(1)$ \\
\hline Jumlah sampel & $\mathbf{3 4}$ \\
\hline Tahun pengamatan & $\mathbf{2}$ \\
\hline Jumlah sampel & $\mathbf{6 8}$ \\
\hline
\end{tabular}

Berdasarkan kriteria di atas, maka kabupaten / kota yang memenuhi kriteria untuk digunakan sebagai populasi dalam penelitian ini adalah sebagai berikut : 
Tabel 2 Kriteria Populasi Penelitian

\begin{tabular}{|c|c|c|c|c|}
\hline No & Kabupaten/Kota & Kriteria 1 & Kriteria 2 & Kriteria 3 \\
\hline 1 & Kabupaten Cilacap & $\mathrm{V}$ & V & $\mathrm{V}$ \\
\hline 2 & Kabupaten Banyumas & $\mathrm{V}$ & $\mathrm{V}$ & $\mathrm{V}$ \\
\hline 3 & Kabupaten Purbalingga & $\mathrm{V}$ & V & $\mathrm{V}$ \\
\hline 4 & Kabupaten Banjarnegara & $\mathrm{V}$ & $\mathrm{V}$ & $\mathrm{V}$ \\
\hline 5 & Kabupaten Kebumen & $\mathrm{V}$ & $\mathrm{V}$ & $\mathrm{V}$ \\
\hline 6 & Kabupaten Purworejo & V & V & $\mathrm{V}$ \\
\hline 7 & Kabupaten Wonosobo & V & V & $\mathrm{V}$ \\
\hline 8 & Kabupaten Magelang & V & $\mathrm{V}$ & $\mathrm{V}$ \\
\hline 9 & Kabupaten Boyolali & $\mathrm{V}$ & $\mathrm{V}$ & $\mathrm{V}$ \\
\hline 10 & Kabupaten Klaten & V & V & $\mathrm{V}$ \\
\hline 11 & Kabupaten Sukoharjo & $\mathrm{V}$ & $\mathrm{V}$ & $\mathrm{V}$ \\
\hline 12 & Kabupaten Wonogiri & V & V & $\mathrm{V}$ \\
\hline 13 & Kabupaten Karanganyar & $\mathrm{V}$ & $\mathrm{V}$ & $\mathrm{V}$ \\
\hline 14 & Kabupaten Sragen & $\mathrm{V}$ & $\mathrm{V}$ & $\mathrm{V}$ \\
\hline 15 & Kabupaten Grobogan & $\mathrm{V}$ & $\mathrm{V}$ & $\mathrm{V}$ \\
\hline 16 & Kabupaten Blora & $\mathrm{V}$ & V & $\mathrm{V}$ \\
\hline 17 & Kabupaten Rembang & $\mathrm{V}$ & $\mathrm{V}$ & $\mathrm{V}$ \\
\hline 18 & Kabupaten Pati & $\mathrm{V}$ & V & $\mathrm{V}$ \\
\hline 19 & Kabupaten Kudus & $\mathrm{V}$ & $\mathrm{V}$ & $\mathrm{V}$ \\
\hline 20 & Kabupaten Jepara & $\mathrm{V}$ & $\mathrm{V}$ & $\mathrm{V}$ \\
\hline 21 & Kabupaten Demak & $\mathrm{V}$ & $\mathrm{V}$ & $\mathrm{V}$ \\
\hline 22 & Kabupaten Semarang & V & V & $\mathrm{V}$ \\
\hline 23 & Kabupaten Temanggung & $\mathrm{V}$ & $\mathrm{V}$ & $\mathrm{V}$ \\
\hline 24 & Kabupaten Kendal & $\mathrm{V}$ & $\mathrm{V}$ & $\mathrm{V}$ \\
\hline 25 & Kabupaten Batang & $\mathrm{V}$ & V & $\mathrm{V}$ \\
\hline 26 & Kabupaten Pekalongan & $\mathrm{V}$ & $\mathrm{V}$ & $\mathrm{V}$ \\
\hline 27 & Kabupaten Pemalang & $\mathrm{V}$ & $\mathrm{V}$ & $\mathrm{X}$ \\
\hline
\end{tabular}




\begin{tabular}{|c|l|c|c|c|}
\hline 28 & Kabupaten Tegal & V & V & V \\
\hline 29 & Kabupaten Brebes & V & V & V \\
\hline 30 & Kota Magelang & V & V & V \\
\hline 31 & Kota Surakarta & V & V & V \\
\hline 32 & Kota Salatiga & V & V & V \\
\hline 33 & Kota Semarang & V & V & V \\
\hline 34 & Kota Pekalongan & V & V & \\
\hline 35 & Kota Tegal & & & \\
\hline
\end{tabular}

Sumber : Badan Pusat Statistik, 2018

Berdasarkan tabel diatas kabupaten /kota di jawa tengah yang tidak memenuhi kriteria sebanyak 1(satu) kabupaten/kota yaitu kabupaten pemalang, sehingga populasi yang digunakan dalam penelitian ini sebanyak 34 (tiga puluh empat) kabupaten/kota.

\section{Analisis Data}

\section{Analisis Statistik Deskriptif}

Analisis deskriptif statistik dilakukan untuk mengetahui sebaran nilai dari variabel-variabel penelitian. Berikut adalah hasil output perhitungan deskriptif statistik :

Tabel 3 Deskriptif Variabel Penelitian di Jawa Tengah 2015-2016

\section{Descriptive Statistics}

\begin{tabular}{|l|r|r|r|r|r|}
\hline & N & Minimum & Maximum & Mean & Std. Deviation \\
\hline PAD & 68 & 74339697 & 1232373211 & 269990498,22 & 173505016,251 \\
DAU & 68 & 400176755 & 1398539653 & 922797051,49 & 246184417,272 \\
DAK & 68 & 3750100 & 519233478 & 159236151,81 & 133094012,439 \\
BD & 68 & 888502644 & 4400015272 & 2099118677,04 & 665916655,313 \\
Valid N (listwise) & 68 & & & & \\
\hline
\end{tabular}

Sumber : Data yang diolah, 2018 
Berdasarkan hasil pengumpulan dan seleksi data penelitian yang dilakukan, diperoleh hasil statistik deskriptif yang ditunjuk pada tabel dapat diinterprestasikan bahwa variabel PAD $\left(\mathrm{X}_{1}\right)$ dari pengamatan sebanyak 68 data memiliki nilai minimumnya sebesar Rp 74.339.697 dengan nilai maksimum sebesar Rp 1.232.373.211. Nilai rata-rata PAD sebesar Rp 269.990.498,22 dengan standar deviasi Rp 173.505.016,251 lebih kecil dari nilai rata-rata sehingga nilai tersebut menunjukan bahwa distribusi data normal.

Hasil pengujian variabel DAU $\left(\mathrm{X}_{2}\right)$ dari pengamatan sebanyak 68 data menunjukan bahwa variabel tersebut memiliki nilai minimum sebesar $\mathrm{Rp}$ 400.176.755 dan nilai maksimum sebesar Rp 1.398.539.653. Nilai rata-rata DAU sebesar Rp 922.797.051,49 dengan standar deviasi Rp 246.184.417,272 lebih kecil dari nilai rata-rata sehingga nilai tersebut menunjukan bahwa distribusi data normal.

Hasil pengujian variabel DAK $\left(\mathrm{X}_{3}\right)$ dari pengamatan sebanyak 68 data menunjukan bahwa variabel tersebut memiliki nilai minimum sebesar Rp 3.750.100 dan nilai maksimum sebesar Rp 519.233.478. Nilai rata-rata DAK sebesar Rp 159.236.151,81 dengan standar deviasi Rp 133.094.012,439 lebih kecil dari nilai rata-rata sehingga nilai tersebut menunjukan bahwa distribusi data normal.

Hasil pengujian variabel Belanja Daerah (Y) dari pengamatan sebanyak 68 data menunjukan bahwa variabel tersebut memiliki nilai minimum sebesar Rp 888.502.644 dan nilai maksimum sebesar Rp 4.400.015.272. Nilai rata-rata BD sebesar Rp 2.099.118.677,04 dengan standar deviasi Rp 665.916.655,313 lebih kecil dari nilai rata-rata sehingga nilai tersebut menunjukan bahwa distribusi data normal. 


\section{Uji Asumsi Klasik}

\section{Uji Normalitas}

Uji normalitas bertujuan untuk menguji apakah dalam model regresi variabel-variabel independen dan dependen mempunyai distribusi normal atau tidak. Berikut hasil olah data normalitas :

Tabel 4 Uji Normalitas Data

One-Sample Kolmogorov-Smirnov Test

\begin{tabular}{|ll|r|}
\hline N & & Unstandardized Residual \\
& & 68 \\
Normal Parameters ${ }^{\mathrm{a}, \mathrm{b}}$ & Mean & $-3 \mathrm{E}-7$ \\
& Std. Deviation & 131691986,36026415 \\
& Absolute &, 085 \\
Most Extreme Differences & Positive &, 085 \\
& Negative &,- 039 \\
Kolmogorov-Smirnov Z & &, 699 \\
Asymp. Sig. (2-tailed) & &, 714 \\
\hline
\end{tabular}
a. Test distribution is Normal.
b. Calculated from data.

Sumber : Data yang diolah, 2018

Berdasarkan tabel diatas dijelaskan besarnya nilai Kolmogorov-Smirnov adalah 0,699 dan data yang digunakan dalam penelitian ini terdistribusi normal dimana nilai asymp.sig sebesar 0,714 yang lebih besar dari tingkat signifikansi penelitian yaitu 0,05 atau 5\% berarti data yang digunakan terdistribusi normal. Maka data dapat digunakan dalam pengujian model regresi dengan variabel dependen Belanja Daerah dan variabel independen Pendapatan Asli Daerah, Dana Alokasi Umum, Dana Alokasi Khusus. 


\section{Uji Multikolinearitas}

Uji multikolinearitas bertujuan untuk menguji apakah dalam suatu model regresi ditemukan adanya korelasi atau hubungan yang signifikan antar variabel bebas (Ghozali, 2013).

Tabel 5 Hasil Uji Multikolinearitas

Coefficients $^{\mathrm{a}}$

\begin{tabular}{|c|c|c|c|c|c|c|c|}
\hline \multirow[t]{2}{*}{ Model } & \multicolumn{2}{|c|}{ Unstandardized Coefficients } & \multirow{2}{*}{$\begin{array}{c}\begin{array}{c}\text { Standardized } \\
\text { Coefficients }\end{array} \\
\text { Beta }\end{array}$} & \multirow[t]{2}{*}{$\mathrm{t}$} & \multirow[t]{2}{*}{ Sig. } & \multicolumn{2}{|c|}{$\begin{array}{c}\text { Collinearity } \\
\text { Statistics }\end{array}$} \\
\hline & B & Std. Error & & & & Tolerance & VIF \\
\hline (Constant) & $-144655500,827$ & 63994933,175 & & $-2,260$ &, 027 & & \\
\hline PAD & 1,824 &, 102 & ,475 & 17,887 & 000 & 865 & 1,156 \\
\hline DAU & 1,930 & 077 & ,714 & 25,091 &, 000 & ,755 & 1,324 \\
\hline DAK &,- 189 &, 133 &,- 038 & $-1,420$ &, 160 & 863 & 1,159 \\
\hline
\end{tabular}

a. Dependent Variable: BD

Sumber : Data yang diolah, 2018

Hasil uji multikolinearitas memperlihatkan bahwa nilai tolerance $>0,10$ dan nilai Variance Inflation Factor (VIF) < 10. Sehingga pada disimpulkan bahwa tidak ada multikolinieritas antara variabel bebas dalam model regresi ini, artinya dalam penelitian variabel independen tidak memiliki korelasi atau hubungan yang sangat kuat.

\section{Uji Autokorelasi}

Uji autokorelasi bertujuan untuk menguji apakah dalam model regresi linear ada korelasi antara kesalahan penggangu pada periode $\mathrm{t}$ dengan kesalahan penggangu pada periode t-1 (sebelumnya) Ghozali (2013).

\section{Tabel 6 Hasil Uji Autokorelasi}

\section{Model Summary}

\begin{tabular}{|l|r|r|r|r|r|}
\hline Model & R & R Square & \multicolumn{1}{|c|}{$\begin{array}{c}\text { Adjusted R } \\
\text { Square }\end{array}$} & $\begin{array}{l}\text { Std. Error of the } \\
\text { Estimate }\end{array}$ & Durbin-Watson \\
\hline 1 &, $980^{\mathrm{a}}$ &, 961 &, 959 & 134743170,698 & 1,918 \\
\hline
\end{tabular}



a. Predictors: (Constant), DAK, PAD, DAU
b. Dependent Variable: BD

Sumber : Data yang diolah, 2018

Berdasarkan uji autokorelasi pada tabel diatas digunakan uji Durbin Watson dengan hasil sebesar 1,918 dengan jumlah data sebanyak 68 sampel $(\mathrm{n}=68)$ dan variabel independen sebanyak $3(\mathrm{k}=3)$. Berdasarkan nilai signifikansi $5 \%$ maka dapat ditentukan nilai (dL) sebesar 1,5164 dan nilai (dU) sebesar 1,7001. Nilai DW 1,918 lebih besar dari batas atas (dU) yakni 1,7001 dan kurang dari (4-dU) 4-1,7001 = 2,2999 sehingga dapat disimpulkan bahwa tidak terjadi autokorelasi.

\section{Uji Heteroskedastisitas}

Uji heteroskedastisitas bertujuan untuk menguji apakah dalam suatu model regresi terjadi ketidaksamaan varians dari residual satu pengamatan ke pengamatan lain Ghozali (2013). Pada penelitian ini menguji ada tidaknya heteroskedastistas adalah dengan menggunakan uji park.

Tabel 7 Hasil Uji Heteroskedastisitas - Uji park

\section{Coefficients $^{\mathrm{a}}$}

\begin{tabular}{|c|c|c|c|c|c|}
\hline \multirow[t]{2}{*}{ Model } & \multicolumn{2}{|c|}{ Unstandardized Coefficients } & \multirow{2}{*}{$\begin{array}{c}\text { Standardized } \\
\text { Coefficients }\end{array}$} & \multirow[t]{2}{*}{$\mathrm{T}$} & \multirow[t]{2}{*}{ Sig. } \\
\hline & B & Std. Error & & & \\
\hline (Constant) & 35,305 & 1,209 & & 29,192 &, 000 \\
\hline PAD & $3,625 \mathrm{E}-009$ &, 000 & ,244 & 1,881 & ,065 \\
\hline DAU & $2,063 \mathrm{E}-011$ & ,000 & ,002 & 014 & ,989 \\
\hline DAK & $-2,454 \mathrm{E}-009$ &, 000 &,- 127 &,- 975 & ,333 \\
\hline
\end{tabular}

a. Dependent Variable: LnU2i

Sumber : Data yang diolah, 2018

Dari tabel diatas dapat dijelaskan bahwa pengujian heterokedastisitas menggunakan uji park diperoleh nilai signifikansi masing-masing variabel lebih 
besar dari 0,05. Sehingga dapat disimpulkan bahwa model regresi tidak terjadi heterokedastisitas karena ketidaksamaan varians dari residual atau pengamatan ke pengamatan lainnya.

\section{Analisis Regresi Linier Berganda}

Analisis regresi linier berganda digunakan untuk mengetahui seberapa besar pengaruh variabel bebas yaitu: PAD, DAU, DAK terhadap Belanja Daerah.

\section{Tabel 8 Hasil Uji Regresi Linear Berganda}

\section{Coefficients $^{\mathrm{a}}$}

\begin{tabular}{|c|c|c|c|c|c|c|c|}
\hline \multirow[t]{2}{*}{ Model } & \multicolumn{2}{|c|}{ Unstandardized Coefficients } & \multirow{2}{*}{\begin{tabular}{|c|}
$\begin{array}{c}\text { Standardized } \\
\text { Coefficients }\end{array}$ \\
Beta \\
\end{tabular}} & \multirow[t]{2}{*}{$t$} & \multirow[t]{2}{*}{ Sig. } & \multicolumn{2}{|c|}{$\begin{array}{c}\text { Collinearity } \\
\text { Statistics }\end{array}$} \\
\hline & B & Std. Error & & & & Tolerance & VIF \\
\hline (Constant) & $-144655500,827$ & 63994933,175 & & $-2,260$ & ,027 & & \\
\hline PAD & 1,824 & , 102 & 475, & 17,887 & 000, & ,865 & 1,156 \\
\hline DAU & 1,930 & ,077 & ,714 & 25,091 & 000 & ,755 & 1,324 \\
\hline DAK &,- 189 & 133 &,- 038 & $-1,420$ & ,160 & 863 & 1,159 \\
\hline
\end{tabular}

a. Dependent Variable: BD

Sumber : Data yang diolah, 2018

Berdasarkan Tabel diatas, maka dapat diperoleh persamaan regresi sebagai berikut :

$$
Y=-144655500,827+1,824 X_{1}+1,930 X_{2}-0,189 X_{3}+e
$$

Keterangan:

$$
\begin{array}{ll}
\mathrm{Y} & =\text { Belanja Daerah } \\
\mathrm{X}_{1} & =\text { Pendapatan Asli Daerah } \\
\mathrm{X}_{2} & =\text { Dana Alokasi Umum } \\
\mathrm{X}_{3} & =\text { Dana Alokasi Khusus } \\
e & =\text { Standar error }
\end{array}
$$

Dari persamaan tersebut dapat dijelaskan: 
1. Variabel Pendapatan Asli Daerah dengan angka koefisiensi regresi sebesar 1,824 bernilai positif yang artinya apabila semakin tinggi PAD maka Belanja Daerah akan meningkat.

2. Variabel Dana Alokasi Umum dengan angka regresi sebesar 1,930 bernilai positif yang artinya apabila semakin tinggi DAU maka Belanja Daerah akan meningkat.

3. Variabel Dana Alokasi Khusus dengan angka koefisiensi regresi sebesar $-0,189$ bernilai negatif yang artinya apabila semakin tinggi DAK maka Belanja Daerah akan menurun.

\section{Uji Hipotesis}

\section{Uji Koefisien Determinasi $\left(\mathbf{R}^{\mathbf{2}}\right)$}

Uji Koefisien determinasi digunakan untuk mengukur seberapa jauh kemampuan model dalam menerangkan variasi variabel dependen, dimana nilai tersebut ditunjukkan dengan nilai Adjusted R Square.

Tabel 9 Hasil Uji Koefisien Determinasi (Uji $\left.\mathbf{R}^{\mathbf{2}}\right)$

\section{Model Summary}

\begin{tabular}{|l|r|r|r|r|}
\hline Model & R & R Square & Adjusted R Square & $\begin{array}{c}\text { Std. Error of the } \\
\text { Estimate }\end{array}$ \\
\hline 1 &, $980^{\mathrm{a}}$ &, 961 &, 959 & 134743170,698 \\
\hline
\end{tabular}

a. Predictors: (Constant), DAK, PAD, DAU

Sumber : Data yang diolah, 2018

Berdasarkan hasil pengujian nilai koefisien determinasi yang ditunjukkan dengan adjusted $R$ square adalah sebesar 0,959 Hal ini dapat diartikan bahwa variabel PAD, DAU, DAK dapat menjelaskan variabel Belanja Daerah sebesar $95,9 \%$ sedangkan sisanya $4,1 \%$ dijelaskan oleh variabel lain yang tidak diamati dalam penelitian ini. 


\section{Uji Simultan (Uji F)}

Pengujian ini bertujuan mengetahui apakah model regresi yang digunakan dalam penelitian layak untuk digunakan sebagai model pengujian data dan hipotesis yang diajukan.

Tabel 10 Hasil Uji Simultan (Uji F)

ANOVA $^{\mathrm{a}}$

\begin{tabular}{|c|c|c|c|c|c|}
\hline Model & Sum of Squares & Df & Mean Square & $\bar{F}$ & Sig. \\
\hline $\begin{array}{l}\text { Regression } \\
\text { Residual } \\
\text { Total }\end{array}$ & $\begin{array}{r}2854884824095 \\
9200000,000 \\
\\
1161966211191 \\
298300,000 \\
2971081445215 \\
0500000,000\end{array}$ & $\begin{array}{r}3 \\
64 \\
67\end{array}$ & $\begin{array}{r}9516282746986 \\
402000,000 \\
\\
1815572204986 \\
4036,000\end{array}$ & 524,148 &, $000^{\mathrm{b}}$ \\
\hline
\end{tabular}

a. Dependent Variable: BD

b. Predictors: (Constant), DAK, PAD, DAU

Sumber : Data yang diolah, 2018

Berdasarkan tabel anova diperoleh nilai $\mathrm{F}_{\text {hitung }} 524,148>\mathrm{F}_{\text {tabel }}$ 2,748 dan nilai signifikansi $0,000<0,05$ ini berarti variabel independen PAD, DAU, DAK secara simultan benar-benar berpengaruh signifikan terhadap variabel Belanja Daerah. Sehingga variabel-variabel independen PAD, DAU, DAK mampu menjelaskan Belanja Daerah. 


\section{Uji Parsial (Uji t)}

Hasil uji signifikansi-t model persamaan dalam penelitian ini dapat dilihat pada tabel berikut ini:

\section{Tabel 11 Hasil Uji Parsial (Uji t) \\ Coefficients $^{\mathrm{a}}$}

\begin{tabular}{|c|c|c|c|c|c|}
\hline \multirow[t]{2}{*}{ Model } & \multicolumn{2}{|c|}{ Unstandardized Coefficients } & \multirow{2}{*}{$\begin{array}{c}\text { Standardized } \\
\text { Coefficients }\end{array}$} & \multirow[t]{2}{*}{$\mathrm{t}$} & \multirow[t]{2}{*}{ Sig. } \\
\hline & B & Std. Error & & & \\
\hline (Constant) & $-144655500,827$ & 63994933,175 & & $-2,260$ & 027 \\
\hline PAD & 1,824 & 102 & ,475 & 17,887 &, 000 \\
\hline DAU & 1,930 & 077 & ,714 & 25,091 &, 000 \\
\hline DAK &,- 189 &, 133 &,- 038 & $-1,420$ &, 160 \\
\hline
\end{tabular}

a. Dependent Variable: BD

Sumber : Data yang diolah, 2018

Hipotesis :

$\mathrm{H}_{\mathrm{o}}=$ Variabel independen tidak berpengaruh terhadap variabel dependen.

$\mathrm{H}_{\mathrm{a}}=$ Variabel independen berpengaruh terhadap variabel dependen.

Tingkat kepercayaan yang digunakan adalah 95\%, maka nilai $\alpha=0,05$

Dasar Pengambilan keputusan :

1. $\mathrm{H}_{\mathrm{a}}$ diterima dan $\mathrm{H}_{\mathrm{o}}$ ditolak jika nilai $\mathrm{t}_{\text {hitung }}>\mathrm{t}_{\text {tabel }}$ atau jika nilai sig. $<0,05$

2. $\mathrm{H}_{\mathrm{a}}$ ditolak dan $\mathrm{H}_{\mathrm{o}}$ diterima jika nilai $\mathrm{t}_{\text {hitung }}<\mathrm{t}_{\text {tabel }}$ atau jika nilai sig. $>0,05$

Berdasarkan hasil analisis menggunakan metode analisis regresi linear berganda dengan hasil pengujian statistik SPSS 20 sebagai berikut :

1. Pengujian pengaruh PAD terhadap Belanja Daerah diperoleh nilai thitung sebesar $17,887>t_{\text {table }} 1,998$ dengan signifikansi sebesar $0,000<0,05$ sehingga, dapat dibuktikan bahwa $\mathrm{H}_{\mathrm{a}}$ diterima dan $\mathrm{H}_{\mathrm{o}}$ ditolak. Ini berarti variabel PAD berpengaruh terhadap Belanja Daerah.

2. Pengujian pengaruh DAU terhadap Belanja Daerah diperoleh nilai $t_{\text {hitung }}$ sebesar $25,091>t_{\text {table }} 1,998$ dengan signifikansi sebesar $0,000<0,05$ sehingga, dapat 
dibuktikan bahwa $\mathrm{H}_{\mathrm{a}}$ diterima dan $\mathrm{H}_{\mathrm{o}}$ ditolak. Ini berarti variabel DAU berpengaruh terhadap Belanja Daerah.

3. Pengujian pengaruh DAK terhadap Belanja Daerah diperoleh nilai thitung sebesar $-1,420<t_{\text {table }}$ 1,998 dengan signifikansi sebesar 0,160>0,05 sehingga, dapat dibuktikan bahwa $\mathrm{H}_{\mathrm{a}}$ ditolak dan $\mathrm{H}_{\mathrm{o}}$ diterima. Ini berarti variabel DAK tidak berpengaruh terhadap Belanja Daerah.

4. Pengujian Flypaper Effect pada Daerah Kaya dan Miskin, hasil pengolahan data menunjukan nilai Standardized Coefficients PAD sebesar 0,475, nilai Standardized Coefficients DAU sebesar 0,714 sedangkan nilai Standardized Coefficients DAK sebesar -0,038. Jika dibandingkan dengan nilai Standardized Coefficients PAD $(0,475)$ dan DAK $(-0,038)$ nilai Standardized Coefficients DAU $(0,714)$ lebih tinggi artinya telah terjadi Flypaper effect pada Pemerintah Kabupaten/Kota di Jawa Tengah.

\section{Pembahasan}

Berdasarkan pengujian yang telah dilakukan, maka peneliti akan menjelaskan secara lebih detail pada pembahasan hasil uji hipotesis. Adapun pembahasan dari setiap hipotesis dalam penelitian ini adalah :

\section{Pengaruh Pendapatan Asli Daerah (PAD) Terhadap Belanja Daerah}

Hasil penelitian menunjukan bahwa PAD memiliki pengaruh terhadap belanja daerah pada pemerintah Kabupaten/Kota di Jawa Tengah. Pada penelitian ini juga sejalan dengan penelitian yang dilakukan Maimunah (2006) dalam Wia Rizqi Amalia (2015), menunjukan bahwa Pendapatan Asli Daerah (PAD) berpengaruh terhadap belanja daerah. Kebijakan Pemerintah Daerah dalam menganggarkan belanja daerah disesuaikan dengan pendapatan yang diterima. Namun di sisi lain, transfer yang diterima dari pemerintah pusat juga turut mempengaruhi besarnya anggaran belanja daerah yang akan dianggarkan oleh Pemerintah Daerah. 


\section{Pengaruh Dana Alokasi Umum (DAU) terhadap Belanja Daerah}

Hasil penelitian menunjukan bahwa Dana Alokasi Umum memiliki pengaruh terhadap Belanja Daerah pada pemerintah Kabupaten/kota di Jawa Tengah. Hal tersebut sejalan dengan penelitian yang dilakukan Maimunah (2006) dalam Wia Rizqi Amalia (2015), Utama (2011) dalam Solikin (2016), Listiorini (2012) dalam Luluk Atika Rahmawati (2015) serta Iskandar (2012) dalam Solikin (2016) menunjukkan bahwa Dana Alokasi Umum (DAU) berpengaruh terhadap belanja daerah. Besar-kecilnya transfer yang dilakukan oleh pemerintah pusat kepada pemerintah daerah dalam bentuk Dana Alokasi Umum (DAU), yang termasuk dalam bagian Dana Perimbangan mempengaruhi alokasi belanja langsung.

\section{Pengaruh Dana Alokasi Khusus (DAK) terhadap Belanja Daerah}

Hasil penelitian Dana Alokasi Khusus bernilai negatif menunjukkan adanya hubungan yang tidak searah antara variabel DAK dan belanja daerah. Selain itu, hasil uji statistik $\mathrm{t}$ variabel DAK memiliki nilai $\mathrm{t}_{\text {hitung }}-1,420<\mathrm{t}_{\text {tabel }} 1,998$ dan nilai signifikansi $0,160>0,05$ menunjukkan bahwa DAK tidak berpengaruh terhadap belanja daerah. Hal tersebut sejalan dengan penelitian yang dilakukan Nahlia (2014) dan Listiorini (2012) dalam Wia Rizqi Amalia (2015) menyimpulkan Dana Alokasi Khusus (DAK) tidak berpengaruh terhadap belanja daerah pada pemerintahan Kabupaten/Kota di Jawa Tengah, menunjukan bahwa dalam penelitian tersebut kemandirian pemerintah daerah dalam membiayai pembangunannya terutama untuk belanja daerah masih bergantung pada dana transfer dari pusat.

\section{Analisis Flypaper Effect pada Daerah Kaya dan Miskin}

Hasil menunjukan bahwa baik pada daerah kaya PAD maupun pada daerah miskin PAD, keduanya mengalami flypaper effect, dimana DAU yang diterima daerah lebih mampu menstimulus daerah untuk melakukan belanja dibanding PADnya sendiri. Dengan demikian, hipotesis keempat yang menyatakan 
daerah dengan PAD rendah dan PAD tinggi mengalami flypaper effect tidak dapat ditolak.

Hal tersebut sejalan dengan penelitian yang dilakukan Maimunah (2006) dalam Marissa Ayu Saputri (2014) Berdasarkan hasil regresi berganda tersebut, diketahui bahwa variabel DAU pada masing-masing kondisi daerah memiliki pengaruh lebih kuat terhadap Belanja Daerah daripada pengaruh PAD terhadap Belanja Daerah. Ini mengindikasikan bahwa flypaper effect tidak hanya terjadi pada daerah dengan PAD rendah namun juga pada daerah dengan PAD tinggi.

\section{PENUTUP}

\section{Kesimpulan}

Setelah menganalisa Flypaper Effect pada Pendapatan Asli Daerah (PAD), Dana Alokasi Umum (DAU), Dana Alokasi Khusus (DAK) terhadap Belanja Daerah pada Pemerintahan Kabupaten / Kota di Jawa Tengah Tahun 2015-2016, maka dapat diambil beberapa kesimpulan sebagai berikut:

1. Berdasarkan hasil penelitian menunjukan bahwa PAD berpengaruh terhadap belanja daerah pada pemerintah Kabupaten/Kota di Jawa Tengah.

2. Berdasarkan hasil penelitian diperoleh bahwa DAU berpengaruh terhadap Belanja Daerah pada pemerintah Kabupaten/Kota di Jawa Tengah.

3. Berdasarkan hasil penelitian diperoleh bahwa DAK tidak berpengaruh terhadap Belanja Daerah pada pemerintah Kabupaten/Kota di Jawa Tengah.

4. Telah terjadi Flypaper effect pada Pemerintah Kabupaten/Kota di Jawa Tengah tahun 2015-2016.

\section{Saran}

Bagi Pemerintah Daerah diharapkan dapat:

1. Menggali sumber-sumber Pendapatan Asli Daerah baik secara intensifikasi maupun extensifikasi untuk meningkatkan pendapatan daerah.

2. Mengoptimalkan potensi ekonomi lokalnya untuk menambah pendapatan daerah sehingga tercipta kemandirian daerah untuk membiayai 
pengeluaran-pengeluaran sehingga pada akhirnya ketergantungan pada Dana Alokasi Umum dapat dikurangi semaksimal mungkin.

\section{Keterbatasan Penelitian}

Penelitian ini memiliki beberapa keterbatasan yang memerlukan perbaikan dan pengembangan dalam penelitian-penelitian berikutnya. Adapun keterbatasan penelitian dimaksudkan adalah sebagai berikut:

1. Data yang diteliti berkenaan dengan penerimaan daerah Kabupaten/Kota di Jawa Tengah baru sebatas PAD, DAU dan DAK.

2. Penelitian ini memiliki beberapa keterbatasan yaitu populasi yang diambil dalam penelitian ini hanya berjumlah 34 kabupaten/kota dari total 35 kabupaten/kota di Jawa Tengah, sehingga hasil penelitian tidak sepenuhnya merepresentasikan fenomena sesungguhnya dari keseluruhan kabupaten/kota yang ada di Jawa Tengah.

\section{Agenda Penelitian yang Akan Datang}

Berdasarkan hasil penelitian dengan adanya keterbatasan penelitian maka penelitian selanjutnya perlu dilakukan perbaikan agar hasilnya menjadi lebih baik maka untuk penelitian selanjutnya perlu :

1. Peneliti selanjutnya diharapkan penerimaan daerah yang akan datang disamping PAD, DAU dan DAK, agar memasukkan komponen lain-lain penerimaan daerah yang sah sebagai variabel penelitian karena merupakan komponen pendapatan daerah.

2. Peneliti selanjutnya diharapkan untuk memperbanyak sensus yang digunakan agar hasilnya lebih respresentatif terhadap populasi yang dipilih dan mengambil sampel selain Kabupaten/Kota di Jawa Tengah 


\section{DAFTAR PUSTAKA}

Darmayasa, I. N. (2012). Flypaper Effect pada Dana Alokasi Umum dan Pendapatan Asli Daerah terhadap Belanja Modal (Studi Kasus pada Kabupaten dan Kota di Bali). Jurnal Bisnis dan Kewirausahaan, 8(3) : $149-157$.

Ghozali, I. (2013). Aplikasi Analisis Multivariate dengan Program SPSS : Cetakan $I V$. Semarang: Badan Penerbit Universitas Diponegoro.

Gregorius N. Masdjojo, S. (2015). TEMA. Pengaruh Pendapatan Asli Daerah dan Dana Perimbangan Terhadap Belanja Daerah Serta Analisis Flypaper Effect Kabupaten/Kota di Jawa Tengah Tahun 2006-2008, Vol.6 Edisi 1.

Halim, A. (2012). Akuntansi Sektor Publik : Akuntansi Keuangan Daerah Edisi 4. Jakarta: Penerbit Salemba 4.

Iskandar, I. (2012). Flypaper Effect pada Unconditional Grant. Jurnal Ekonomi Pembangunan Publikasi Ilmiah UMS, 13 (1), 113-131.

Listiorini. (2012). Fenomena Flypaper Effect pada Dana Perimbangan dan Pendapatan Asli Daerah terhadap Belanja Daerah pada Kabupaten/Kota di Sumatera Utara. Jurnal Keuangan dan Bisnis, Vol. 4 No.2.

Luluk Atika Rahmawati, B. S. (2015). Flypaper Effect Dana Alokasi Umum dan Pendapatan Asli Daerah terhadap Belanja Daerah. Jurnal Ilmu \& Riset Akuntansi, Vol.4 No.9. 
Maimunah. (2006). Flypaper Effect pada Dana Alokasi Umum dan Pendapatan Asli Daerah terhadap Belanja Daerah pada Kabupaten/Kota di Pulau Sumatera. Simponsium Nasional Akuntansi XI, Padang, Indonesia.

Marissa Ayu Saputri, D. M. (2014). Flypaper Effect pada Dana Alokasi Umum dan Pendapatan Asli Daerah Terhadap Belanja Daerah pada Kabupaten/kota di Jawa Tengah 2011-2012. Diponegoro Journal of Accounting, Volume 3, Nomor2, Halaman 1-11 ISSN(online): 2337-3806.

Mentayani, I. N. (2012). Flypaper Effect pada Dana Alokasi Umum dan Pendapatan Asli Daerah terhadap Belanja Daerah pada Kabupaten dan Kota di Provinsi Kalimantan Selatan. Jurnal SPREAD, 2(1), 55-64.

Nahlia, F. (2014). Flypaper Effect pada Pendapatan Asli Daerah, Dana Alokasi Umum, dan Dana Alokasi Khusus terhadap Belanja Daerah pada Kabupaten/Kota di Provinsi Kepulauan Riau Periode 2007-2012. Jurnal Universitas Maritim Raja Ali Haji (UMRAH).

Solikin, A. (2016). Analisis Flypaper Effect Pada Pengujian Pengaruh Dana Alokasi Umum (DAU), Pendapatan Asli Daerah (PAD), dan Sisa Lebih Penghitungan Anggaran (SILPA) terhadap Belanja Pemerintahan Daerah di Indonesia (Studi Tahun 2012-2014). Jurnal Akuntansi dan Bisnis, Vol.16 No.1 Februari 2016: 11-25.

Undang-Undang No.32 Tahun 2004 tentang Pemerintah Daerah.

Undang-Undang No.33 Tahun 2004. Perimbangan Keuangan Antara Pemerintah Pusat dan Pemerintah Daerah. Jakarta: Lembaran Negara Republik Indonesia Tahun 2004. 
Wia Rizqi Amalia, W. N. (2015). Flypaper Effect Pada Pendapatan Asli Daerah (PAD), Dana Alokasi Umum (DAU) dan Dana Alokasi Khusus (DAK) Terhadap Belanja Daerah Pada Pemerintahan Kabupaten/Kota Di Provinsi Kalimantan Selatan (2009-2013). Jurnal Akuntansi dan Bisnis, Vol.15, No.1, Februari 2015: 1-12. 